\title{
Does psychological profile have something to do with satisfaction? A French retailing franchisees study
}

\author{
Véronique Guilloux*
}

Université Paris 12 - IRG Immeuble La Pyramide, 80, av du général de Gaulle, 94009 Créteil cedex, France and

EM Strasbourg, Université de Strasbourg,

HuManiS (EA 13 47) Humans and Management in Society, France

E-mail: veronique.guilloux@univ-paris12.fr

*Corresponding author

\section{Claire Gauzente}

GRANEM - University of Angers,

and

ESC Rennes School of Management,

France UFR de Droit, Economie et Gestion,

13 allée F. Mitterrand, 49036 Angers cedex 01, France

E-mail: claire.gauzente@univ-angers.fr

\begin{abstract}
The main purpose of this study is to analyse the relationship between franchisee's personality and franchisee's satisfaction. A sample of 400 French franchisees concerning different sectors is analysed in detail. In the first part of the article, the methodology is presented. Then, theoretical framework concerning satisfaction and personality is developed. Different hypotheses are justified crossing the MSQ scale and the big four model. Conscientiousness seems to be the most predictive factor for satisfaction and results show that the other Big-Five traits are specific in several sectors.
\end{abstract}

Keywords: franchisees; psychological profile; personality; satisfaction.

Reference to this paper should be made as follows: Guilloux, V. and Gauzente, C. (2010) 'Does psychological profile have something to do with satisfaction? A French retailing franchisees study', Int. J. Entrepreneurship and Small Business, Vol. 11, No. 2, pp.165-182.

Biographical notes: Véronique Guilloux is Assistant Professor at Paris 12 University in an International Management Master. Her research is linked with marketing and e-management. Her work has been published in Journal of Small Business Management and International Journal of Entrepreneurship and Small Business.

Claire Gauzente is Professor of Marketing and Organisation at the Institute of Political Sciences, Rennes France. Her research interests include franchise management, interactive marketing, and research methods. Her work has been published in, among others, Journal of Small Business Management, International Journal of Retail and Distribution Management and Academy of Marketing Science Review. 


\section{Introduction}

Franchising is a major component of the French distribution system. French franchise system holds the leader position in Europe in terms of sales (http://www.franchisefff.com/).

Numerous magazines explain to a wide audience, franchise opportunities, but the academic community seems to be lacking of theoretical frames. Many handbooks show the important role of the franchisee concerning the success of a franchise network, but paradoxically few empirical researches have tried to understand the psychological antecedents (personality) of satisfaction (except Morrison, 1997; Schell and McGillis, 1990; Tuunanen, 1999). Study of the scientific literature, in addition to examining our own exploratory interviews, has persuaded us to retain the variable 'psychological profile of franchisees' to explain satisfaction. The main purpose of this study is to analyse the relationship between franchisee's personality and franchisee's satisfaction. A sample of 400 French franchisees concerning different sectors is analysed in detail. In the first part of the article the methodology is presented. Then theoretical framework concerning satisfaction and personality is developed. Different hypotheses are justified crossing the MSQ scale and the big four model. Results of the empirical study are then detailed. Directions for future research are outlined.

\section{Methodology: sample and sectors}

This research was funded by the French Franchise Federation. Several stages must be identified in our research. The diagram below synthesises the various phases involved in collecting data.

Figure 1 The collection of data

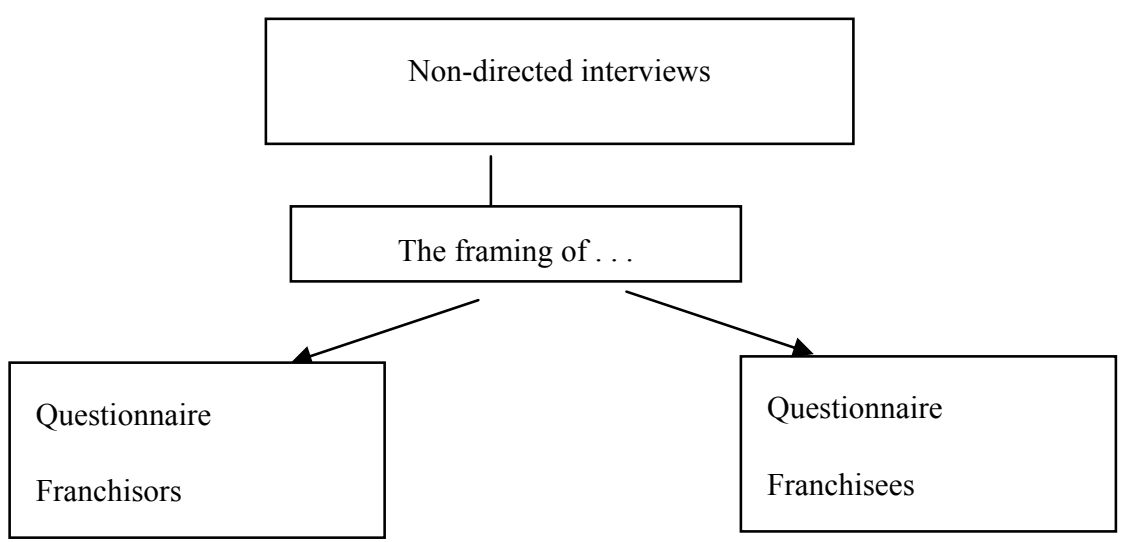

A guide was developed to interviewing technique, in order to establish qualitatively franchisees' motivations, their reasons for satisfaction and their selection processes (approached through accounts of their own experience). Twenty one in-depth interviews were carried out with franchisees. Industrial sectors were as follows: property, fast food, optics, food distribution, automobiles, clothing textiles, hairdressing, wines and spirits, soft furnishings and shoes. 
By the end of this first stage, two questionnaires were framed:

- questionnaire for franchisors: questions dealing with their perception of the reasons for selecting applicants for franchising

- questionnaire for franchisees: identity, psychological profile, type of relationship with franchisors and satisfaction.

Table 1 Questioning methodology

\begin{tabular}{|c|c|c|c|}
\hline Characteristics & $\begin{array}{l}\text { Survey of potential } \\
\text { franchisees } \\
\text { Preliminary survey of } \\
\text { franchisees }\end{array}$ & Survey of franchisors & Survey of franchisees \\
\hline Target & $\begin{array}{c}\text { Franchisees } \\
\text { (qualitative method) }\end{array}$ & Franchisors & Franchisees \\
\hline $\begin{array}{l}\text { - Means of } \\
\text { collection }\end{array}$ & $\begin{array}{c}\text { Face to face } \\
\text { interviews } \\
\text { In-depth interviews }\end{array}$ & $\begin{array}{c}\text { Face to face } \\
\text { interviews and } \\
\text { questioning by post }\end{array}$ & $\begin{array}{l}\text { Telephone interviews } \\
\text { carried out by GFK }\end{array}$ \\
\hline - Overall population & $\begin{array}{l}21 \text { interviews were } \\
\text { conducted in four } \\
\text { different regions of } \\
\text { France }\end{array}$ & $\begin{array}{l}\text { List of franchisors in } \\
\text { the Franchise } \\
\text { Yearbook (240) }\end{array}$ & $\begin{array}{l}\text { List of } 4,659 \\
\text { franchisees }\end{array}$ \\
\hline - Size of sample & 21 franchisees & 88 questionnaires & 400 questionnaires \\
\hline
\end{tabular}

In this paper, we focus on the franchisee population.

The aim was to acquire a representative sample of franchisees. Defining the research quotas was achieved in four phases:

- Calculating with the help of the Franchise Yearbook the percentages of franchises in each sector.

Table 2 The overall population

\begin{tabular}{llcccc}
\hline & $\begin{array}{c}\text { Number of } \\
\text { franchisors }\end{array}$ & $\begin{array}{c}\text { Number of } \\
\text { franchisees }\end{array}$ & $\begin{array}{c}\% \\
\text { franchisors }\end{array}$ & $\begin{array}{c}\% \\
\text { franchisees }\end{array}$ \\
\hline 1 & Specialised food trade & 30 & 982 & $8.26 \%$ & $3.98 \%$ \\
2 & Non-specialised food trade & 8 & 2,873 & $2.20 \%$ & $11.63 \%$ \\
3 & Personal equipment & 71 & 4,396 & $19.56 \%$ & $17.80 \%$ \\
4 & Household equipment & 47 & 2,410 & $12.95 \%$ & $9.76 \%$ \\
5 & Other non-food specialised & 48 & 2,878 & $13.22 \%$ & $11.65 \%$ \\
& businesses & & & & \\
6 & Services & 101 & 8,619 & $27.82 \%$ & $34.90 \%$ \\
7 & Hotels and restaurants & 46 & 2,198 & $12.67 \%$ & $8.90 \%$ \\
8 & Building & 12 & 342 & $3.31 \%$ & $1.38 \%$ \\
Total & 363 & 24,698 & $100.00 \%$ & $100.00 \%$ \\
\hline
\end{tabular}

- Requesting 240 franchisors to supply a list of their franchisees. A mailing has been done with French Franchise Federation headed notepaper.

- Receiving 40 lists comprising 4,659 franchisees. 
Table 3 The answers obtained from the franchisors

\begin{tabular}{|c|c|c|c|c|c|}
\hline & & $\begin{array}{l}\text { Number of } \\
\text { franchisors }\end{array}$ & $\begin{array}{l}\text { Number of } \\
\text { franchisees }\end{array}$ & $\begin{array}{c}\% \\
\text { franchisors }\end{array}$ & $\begin{array}{c}\% \\
\text { franchisees }\end{array}$ \\
\hline 1 & Specialised food trade & 5 & 270 & $12.50 \%$ & $5.80 \%$ \\
\hline 2 & Non-specialised food trade & 3 & 1,491 & $7.50 \%$ & $32.00 \%$ \\
\hline 3 & Personal equipment & 7 & 358 & $17.50 \%$ & $7.68 \%$ \\
\hline 4 & Household equipment & 3 & 299 & $7.50 \%$ & $6.42 \%$ \\
\hline 5 & $\begin{array}{l}\text { Other specialised non-food } \\
\text { businesses }\end{array}$ & 7 & 535 & $17.50 \%$ & $11.48 \%$ \\
\hline 6 & Services & 11 & 1,364 & $27.50 \%$ & $29.28 \%$ \\
\hline 7 & Hotels and restaurants & 3 & 332 & $7.50 \%$ & $7.13 \%$ \\
\hline & Building & 1 & 10 & $2.50 \%$ & $0.21 \%$ \\
\hline \multicolumn{2}{|c|}{ Total } & 40 & $4,659^{1}$ & $100.00 \%$ & $100.00 \%$ \\
\hline
\end{tabular}

Note: ${ }^{1}$ That is, $18.86 \%$ of the base population.

- Calculating the quotas of franchisees to question, bearing in mind that our aim is to collect 400 valid questionnaires. This number has been chosen in partnership with GFK and the French Franchise Federation.

Table 4 The makeup of research quotas

\begin{tabular}{|c|c|c|c|c|}
\hline & & $\begin{array}{l}\text { Number of } \\
\text { franchisees to be } \\
\text { questioned }^{l}\end{array}$ & Name of franchisors & $\begin{array}{l}\text { Number of } \\
\text { franchisees } \\
\text { interviewed }\end{array}$ \\
\hline \multirow[t]{3}{*}{1} & \multirow{3}{*}{$\begin{array}{l}\text { Specialised food } \\
\text { trade }\end{array}$} & \multirow[t]{3}{*}{16} & Point chaud & 1 \\
\hline & & & Comtesse du Barry & 9 \\
\hline & & & Deneuville & 6 \\
\hline \multirow[t]{3}{*}{2} & \multirow{3}{*}{$\begin{array}{l}\text { Non-specialised food } \\
\text { trade }\end{array}$} & \multirow[t]{3}{*}{47} & Casino & 15 \\
\hline & & & Huit à Huit & 18 \\
\hline & & & Champion & 14 \\
\hline \multirow[t]{5}{*}{3} & \multirow[t]{5}{*}{ Personal equipment } & \multirow[t]{5}{*}{71} & Rodier & 14 \\
\hline & & & $\begin{array}{l}\text { La compagnie des } \\
\text { petits }\end{array}$ & 23 \\
\hline & & & Phildar & 30 \\
\hline & & & Petit Boy & 2 \\
\hline & & & Descamps & 2 \\
\hline \multirow[t]{3}{*}{4} & \multirow[t]{3}{*}{ Household equipment } & \multirow[t]{3}{*}{39} & Catena & 16 \\
\hline & & & Maison de la Literie & 21 \\
\hline & & & $\begin{array}{l}\text { Cuisines Plus/Bains } \\
\text { plus }\end{array}$ & 2 \\
\hline
\end{tabular}

Note: ${ }^{1}$ The number of franchisees in each sector is calculated by multiplying the total number of the sample by the percentage of franchisees in the sector in question in the base population. For example, in the specialised food trade, the statistics of the base population show that the franchisees of that sector represent $3.98 \%$ of all

French franchisees. Thus, in our survey we must question $3.98 \%$ of 400 , that is, 16 franchisees. 
Table 4 The makeup of research quotas (continued|)

\begin{tabular}{|c|c|c|c|c|}
\hline & & $\begin{array}{c}\text { Number of } \\
\text { franchisees to be }^{\text {questioned }}\end{array}$ & Name of franchisors & $\begin{array}{l}\text { Number of } \\
\text { franchisees } \\
\text { interviewed }\end{array}$ \\
\hline \multirow[t]{5}{*}{5} & \multirow{5}{*}{$\begin{array}{l}\text { Other specialised } \\
\text { non-food businesses }\end{array}$} & \multirow[t]{5}{*}{47} & La Trocante & 17 \\
\hline & & & Bazar Land & 10 \\
\hline & & & Magasin Gamm Vert & 11 \\
\hline & & & Troc De L'île & 1 \\
\hline & & & Distri Club Medical & 8 \\
\hline \multirow[t]{10}{*}{6} & \multirow[t]{10}{*}{ Services } & \multirow[t]{10}{*}{140} & Mister Mint & 15 \\
\hline & & & $\begin{array}{l}\text { Jack Hiolt Quick } \\
\text { Service }\end{array}$ & 19 \\
\hline & & & L'onglerie & 20 \\
\hline & & & Speedy & 11 \\
\hline & & & L'age D'or Services & 12 \\
\hline & & & Feu Vert & 5 \\
\hline & & & Mod'hair & 5 \\
\hline & & & Unicis & 6 \\
\hline & & & Etape Auto & 7 \\
\hline & & & Century 21 & 42 \\
\hline \multirow[t]{3}{*}{7} & \multirow[t]{3}{*}{$\begin{array}{l}\text { Hotels and } \\
\text { restaurants }\end{array}$} & \multirow[t]{3}{*}{36} & $\begin{array}{l}\text { Comfort, Quality } \\
\text { Hotels }\end{array}$ & 11 \\
\hline & & & Café Leffe & 17 \\
\hline & & & Quick & 8 \\
\hline 8 & Building & 0 & & \\
\hline & & 400 & & \\
\hline
\end{tabular}

Note: ${ }^{1}$ The number of franchisees in each sector is calculated by multiplying the total number of the sample by the percentage of franchisees in the sector in question in the base population. For example, in the specialised food trade, the statistics of the base population show that the franchisees of that sector represent $3.98 \%$ of all French franchisees. Thus, in our survey we must question $3.98 \%$ of 400 , that is, 16 franchisees.

Questioning was carried out on the telephone by GFK ${ }^{1}$. Four hundred valid franchisees' questionnaires were obtained and used in order to test our model for researching the level of satisfaction among franchisees.

\section{Concepts of personality and satisfaction}

We now present the variable 'psychological profile' from a conceptual point of view, going on to investigate the connections between franchisees' profiles and satisfaction. 


\subsection{Personality}

There are many current theories on personality. We look at the main ones, before explaining which of them we selected as appropriate to our study.

\subsubsection{The different approaches}

According to Cattell, the history of personality theories can be divided into three periods. The first was literary, philosophical and intuitive (Hippocrates). In the second, an extensive process of theorisation took place (psycho-analytical theory, Freud, Jung and so on). The third was quantitative and operational, and the notion of distinctive traits came to the fore (Murray, Gordon and others). Writers sought to isolate useful and accurate dimensions to define individuals. No longer is it our aim to discover the unconscious reasons that underlie individual behaviour: it is rather to identify individual differences that are sufficiently stable for us to denominate them as traits of the personality. To establish these differences, we start by making inventories of the personality made up of several hundred questions. The replies enable us to define the individual in relation to personality traits such as aggression, the need for change, dependence, autonomy, exhibitionism and so on. The trait point view assumes that people possess predisposition, called personality traits which refer to patterns in the way individuals behave, feel and think. This approach is based on a nomothetic focus (which studies what the humans have in common and tries to draw general laws) opposed to idiographic process (which favours case studies). Besides, traits approaches to personality emphasises the human's internal working rather than the characteristics of the situation.

The best known quantitative model is a model based on five dimensions, the so-called Big-Five, which are said to compose the main aspects of personality (Pervin and John, 2001). The Big-Five are now considered indispensable to researchers in management or psychology who may be working on problems of personality.

\subsubsection{Conception}

Using Big-Five analysis, there are two types of methods for defining personality: the lexical approach (using simple adjectives) and the classical questionnaire (in the form of sentences).

The material used as a corpus is based on lexical analysis of those terms most commonly used in the natural languages to describe the personalities of individual people. Character traits are revealed in ordinary social interaction and are expressed in everyday language (John et al., 1988). The psychologist seeking to paint a panoramic view of personality traits needs only to consult a dictionary. Peabody (1987) and Peabody and Goldberg (1989) both show that personalities can be assessed with the help of simple adjectives.

The approach through a classical questionnaire depends on using whole sentences. One can offer the example of Costa and McCrae (1988) who base their questions on the Big-Five. 


\subsubsection{The scale}

We explain which structural model of personality we chose for our research, and more particularly why we opted for the lexical method. We shall present the questionnaire we used.

\section{Choosing the Big-Five model}

We stayed with the Big-Five to define franchisees' personalities. The choice was made for several reasons: the model is recognised by the scientific community having been tested in many countries; numerous studies relate the Big-Five to performance (Robertson et al., 1999) and our theme falls within the framework of industrial marketing with a managerial perspective.

\section{Choosing the lexical method}

From the various models we have selected the lexical method. Indeed, using the telephone to conduct our questionnaire dictated the need for a brief form of words.

In the study by Borkenau and Ostendorf (1998): the number of items is small (30); the adjectives are familiar and easily understood; the list has already been tested in a European context. The following table sets out the various adjectives applying to each of the super-factors. Each dimension is evaluated in the left-hand column, with the help of three positive adjectives and three opposed ones. Each dimension is tied with six items.

Table 5 Borkenau and Ostendorf's items

\begin{tabular}{lc}
\hline \multicolumn{1}{c}{ Speaking for yourself, and completely frankly, are you?: } \\
\hline Intellect $(+/-)$ \\
$(-)$ Easily beaten, easily lost, out of one's depth \\
Witty, quick-minded & $(-)$ Unaware, rash \\
Well informed, well documented, expert & $(-)$ Unimaginative \\
Cautious & Conscientiousness $(+/-)$ \\
Hard working & $(-)$ Nonchalant \\
Persistent & $(-)$ Imprudent, unthinking \\
Serious, responsible & $(-)$ Instable \\
& Extraversion $(+/-)$ \\
Dynamic & $(-)$ Timid \\
Sociable & $(-)$ Silent, taciturn \\
Full of drive & $(-)$ Reserved \\
& $(-)$ Selfish \\
Easy to get on with & $(-)$ Authoritarian \\
Obliging & $(-)$ Obstinate \\
Thoughtful, considerate & Agreeableness $(+/-)$ \\
Irritable & $(-)$ Emotionally stable \\
Ill-natured & $(-)$ Calm \\
Vulnerable & $(-)$ Tough
\end{tabular}


In our questionnaire, we placed items in alphabetical order, to maintain strict objectivity. We asked people to respond spontaneously to each item via note from 0 to 10 points. The Big-Five approach is based on factor analysis. Several factors analysis has been done to have a good quality of representation. Only nine items have been selected representing the four factors of the Big-Five.

Table 6 Quality de representation

\begin{tabular}{lcc}
\hline Speaking for yourself, and completely frankly & Initial & Extraction \\
\hline you are imprudent; unthinking & 1,000 &, 679 \\
you are...irritable & 1,000 &, 783 \\
you are reserved & 1,000 &, 722 \\
you are tough & 1,000 &, 638 \\
you are serious responsible & 1,000 &, 614 \\
you are silent, taciturn & 1,000 &, 642 \\
you are witty, quick-minded & 1,000 &, 891 \\
you are persistent & 1,000 &, 609 \\
you are hard working & 1,000 &, 649 \\
\hline
\end{tabular}

Table 7 Factor analysis after rotation (varimax)

\begin{tabular}{|c|c|c|c|c|c|}
\hline & \multirow{2}{*}{$\begin{array}{c}\text { Speaking for yourself, and completely } \\
\text { frankly, }\end{array}$} & \multicolumn{4}{|c|}{ Factors } \\
\hline & & 1 & 2 & 3 & 4 \\
\hline \multirow[t]{4}{*}{ Conscientiousness } & you are tough &, 791 & & & \\
\hline & you are hard working & ,753 & & &,- 208 \\
\hline & you are persistent &, 742 & & & ,222 \\
\hline & you are serious responsible &, 730 & & & ,238 \\
\hline Extraversion (-) & you are reserved & &, 842 & & \\
\hline Introversion $(+)$ & you are silent taciturn & &, 771 & & \\
\hline \multirow[t]{2}{*}{ Neuroticism } & you are...irritable & & &, 866 & \\
\hline & you are imprudent; unthinking &,- 228 & &, 742 & \\
\hline Intellect & you are witty, quick-minded & & & & ,936 \\
\hline
\end{tabular}

The total percentage of the variance accounted for by these four factors is $69,181 \%$. (factor $1-26,337 \%$; factor $2-15,373 \%$, factor $3-15,309 \%$, factor $4-12,162 \%$ ). The Big-Five are represented with conscientiousness; extraversion $(-) /$ introversion $(+)$; neuroticism; intellect.

\subsection{Satisfaction among franchisees}

Before setting out the approach we favoured in the context of this research, we shall describe the approaches that were used in previous studies where the problems of franchising were specifically targeted.

\subsubsection{Approaches used in the specialised literature}

Channel satisfaction and job satisfaction will be reviewed. 


\section{Channel satisfaction}

In studies on the satisfaction of franchisees, channel satisfaction is generally conceptualised as a response of individual channel members towards salient aspects of the channel organisation. For Schul et al. (1985), a franchisee's overall satisfaction with the channel arrangement is based on his specific feelings regarding the quality of: franchise administration, service support, rewards and franchise fee policies. For Lewis and Lambert (1991), satisfaction is tied with three concepts: satisfaction with multiple dimensions of role performance, overall satisfaction with role performance and satisfaction with business decision. Role performance was evaluated by using 117 items distributed among eight business functions (product, physical distribution/customer service, operations, promotion, real estate and construction, pricing, personnel, training). Overall satisfaction was measured by a continuum from 'poor' to 'excellent'. Finally, a single item measure was used to assess how satisfied franchisees were with their initial decision to join the franchise system. Hing's $(1995,1997)$ approach proposes a model for the determining factors of franchisees' satisfaction. Inspired by models of consumers' behaviour, she measures satisfaction against a series of items characterising the activity of the franchise.

\section{Job satisfaction}

The global or faceted approaches can be utilised to measure the satisfaction of franchisees at work. The global approach is used in Brayfield and Rothe (1951). The item was 'I am really very satisfied with my work' or 'I take a real pleasure in my work'. In the faceted approaches, the identification of the multi-facets of job has done a lot of publications (Heneman et al., 1989). The scale that is utilised to measure job satisfaction is for example: the Minnesota satisfaction questionnaire (MSQ) (Weiss et al., 1967).

\subsubsection{The scale}

The approach that we have preferred in the present study takes several considerations into account. Firstly, in conformity with earlier theoretical developments, job satisfaction is measured through facets. Speaking generally, the MSQ is one of the most widely used studies and was also used in Morrison's research. Moreover, in the French context, a reliable translation of this scale is available. Secondly, nevertheless, it seemed to us after our exploratory interviews that the items in the short version (20 items) were not all applicable in the context of franchising. Accordingly, our team selected and adapted items to suit the aims and the context of our research. The resulting scale for the franchisee's job satisfaction comprises nine items. Moreover, as regards remuneration, we thought it important to distinguish several levels: remuneration as payment for the work done, which is an integral part of the MSQ and thus of job satisfaction; remuneration arising from the efficient running of the franchised outlet, with two distinctions: the volume of turnover and the profitability of the franchised outlet.

It also became clear in the course of our exploratory interviews that some dimensions could be linked, such as satisfaction as to the location of the franchised outlet.

In total, the items we have used are as follows with a note from 0 to 10 : 
Table 8 Items selected for measuring the satisfaction of franchisees

\begin{tabular}{|c|c|c|}
\hline \multicolumn{2}{|c|}{ Wording of the items } & Origin \\
\hline \multicolumn{3}{|c|}{ In your present franchise, are you satisfied: } \\
\hline 1 & With the working conditions? & MSQ \\
\hline 2 & With the social status that your work gives you? & MSQ \\
\hline 3 & With the security of your job? & MSQ \\
\hline 4 & That you can use your personal qualities? & MSQ \\
\hline 5 & That you can take decisions on your own initiative? & MSQ \\
\hline 6 & With your occupation during the working day? & MSQ \\
\hline 7 & That you can put into practice your own methods of working? & MSQ \\
\hline 8 & With the feeling of achievement that your work offers you? & MSQ \\
\hline 9 & With your income in relation to the work you do? & MSQ \\
\hline 10 & With the annual turnover you have achieved over the past three years? & HING \\
\hline 11 & With the profitability you have achieved over the past three years? & HING \\
\hline 12 & $\begin{array}{l}\text { All things considered, do you intend to remain in your present } \\
\text { network? }\end{array}$ & HING \\
\hline 13 & All things considered, would you recommend the franchise to a friend? & Our own measure \\
\hline
\end{tabular}

During the Salon de la Franchise, a pre-test for this scale was carried out with franchisees.

The calculation of the alpha for the reliability of the scale for franchisees' job satisfaction as applied to the pre-test sample gives a good result. This was confirmed against the definitive national sample.

Table 9 Reliability study for job satisfaction applied to franchisees

\begin{tabular}{|c|c|c|c|}
\hline \multicolumn{2}{|c|}{ Items MSQ } & \multirow{2}{*}{$\begin{array}{l}\text { Scale without item pre-test } \\
\qquad N=21\end{array}$} & \multirow{2}{*}{$\begin{array}{l}\text { Scale without item } \\
\qquad N=401\end{array}$} \\
\hline & Are you satisfied: & & \\
\hline 1 & With your working conditions? & .8622 & .8634 \\
\hline 2 & $\begin{array}{l}\text { With the social status that your work } \\
\text { gives you? }\end{array}$ & .8680 & .8594 \\
\hline 3 & With the security of your job? & .8808 & .8601 \\
\hline 4 & $\begin{array}{l}\text { That you can use your personal } \\
\text { qualities? }\end{array}$ & .8799 & .8618 \\
\hline 5 & $\begin{array}{l}\text { That you can take decisions on your own } \\
\text { initiative? }\end{array}$ & .8721 & .8629 \\
\hline 6 & $\begin{array}{l}\text { With your occupation during the } \\
\text { working day? }\end{array}$ & .8864 & .8672 \\
\hline 7 & $\begin{array}{l}\text { That you can put into practice your own } \\
\text { working methods? }\end{array}$ & .8756 & .8755 \\
\hline 8 & $\begin{array}{l}\text { With the feeling of achievement that } \\
\text { your work offers you? }\end{array}$ & .8786 & .8550 \\
\hline 9 & $\begin{array}{l}\text { With your income in relation to the work } \\
\text { you do? }\end{array}$ & .9255 & .8793 \\
\hline \multicolumn{2}{|c|}{ Number of items $=9$} & Alpha $=.8939$ & Alpha $=.8782$ \\
\hline
\end{tabular}


We may note that transposing the MSQ to the context of franchising retains the reliability qualities of the measuring scale. Over the definitive survey, the good internal consistence of the scale is amply confirmed; this enables us, firstly, to use the sum of the nine items to evaluate job satisfaction. This procedure is also legitimised by a factorial analysis that extracts a single factor according to the criterion of proper value (\% of variance explained: $\sim 52 \%$, KMO: .885).

\section{Satisfaction and psychological profile}

Support for the relationship between Big-Five personality traits and job performance or job behaviour predictors can be attributed to several meta-analyses. Two of the earliest meta-analyses are those of Barrick and Mount (1991) and Tett et al. (1991). Many different academic authors have reported a relationship between the Big-Five Model and job performance/success or career satisfaction.

Intellect: sometimes called openness to experience, comprises the capacity for knowledge and analytical thinking. DeNeve and Cooper (1998) noted that 'openness to experience is a 'double-edged sword' that predisposes individuals to feel both the good and the bad more deeply' (p.199), rendering its directional influence on job satisfaction unclear.

H1 Intellect is negatively connected to satisfaction

Conscientiousness: Organ and Lingl (1995), Barrick and Mount (1991) and Judge et al. (2002) showed that Conscientiousness should be related to work satisfaction because it means a job involvement tendency which leads to a greater likelihood of obtaining satisfying work rewards.

H2 Conscientiousness is positively connected to satisfaction

Extraversion: extraverts are predisposed to experience positive emotions (Costa and McCrae, 1992) and positive emotionality likely generalises to job satisfaction (Connolly and Viswesvaran, 2000; White et al., 2004). Extraverts have more friends than introverts and, because of their social facility, are likely to find interpersonal interactions more rewarding (Watson and Clark, 1992).

H3 Extraversion is positively connected to satisfaction

Agreeableness: McCrae and Costa (1991) and White et al. (2004) argued that Agreeableness should be related to happiness because it leads to greater motivation to achieve interpersonal intimacy and greater levels of well-being. Mount et al. (1998) demonstrated that agreeableness is a good predictor in jobs where interpersonal interaction and teamwork are important.

H4 Agreeableness is positively connected to satisfaction

Neuroticism: Because of their essentially negative nature, neurotic individuals experience more negative life events than other individuals (Magnus et al., 1993). They select themselves into situations that foster negative effect (Emmons et al., 1985).

H5 Neuroticism is negatively connected to satisfaction 


\section{Results of the empirical study}

Five hypotheses are proposed: H1 - Intellect is negatively connected to satisfaction; $\mathrm{H} 2$ - Conscientiousness is positively connected to satisfaction; H3 - Extraversion is positively connected to satisfaction; H4 - Agreeableness is positively connected to satisfaction and H5 - Neuroticism is negatively connected to satisfaction.

Starting from our index of 400 representative franchisees, we investigated the different research hypotheses relating franchisees' personalities to their level of satisfaction.

Table 10 Pearson correlations

\begin{tabular}{|c|c|c|c|c|c|}
\hline & & Conscientiousness & Introversion & Neuroticism & Intellectual \\
\hline \multirow[t]{2}{*}{ MSQ } & $\begin{array}{c}\text { Corr } \\
\text { Pearson }\end{array}$ & $.399(* *)$ & -.061 & .000 & .042 \\
\hline & $\begin{array}{c}\text { Sig. } \\
\text { (bilateral) }\end{array}$ & .000 & .226 & .997 & .401 \\
\hline $\begin{array}{l}\text { In your present } \\
\text { franchise, are you } \\
\text { satisfied with the } \\
\text { annual turnover you } \\
\text { have achieved over } \\
\text { the past three years }\end{array}$ & Corr & $.226(* *)$ & .013 & -.003 & -.045 \\
\hline $\begin{array}{l}\text { In your present } \\
\text { franchise, are you } \\
\text { satisfied with the } \\
\text { profitability you have } \\
\text { achieved over the past } \\
\text { three years? }\end{array}$ & Corr & $.217(* *)$ & .087 & .012 & -.028 \\
\hline $\begin{array}{l}\text { All things considered, } \\
\text { do you intend to }\end{array}$ & Corr & $.311(* *)$ & -.034 & .018 & -.038 \\
\hline $\begin{array}{l}\text { remain in your } \\
\text { present network? }\end{array}$ & Sig. & .000 & .495 & .723 & .446 \\
\hline $\begin{array}{l}\text { All things considered, } \\
\text { would you }\end{array}$ & Corr & $.274(* *)$ & -.028 & -.020 & -.079 \\
\hline $\begin{array}{l}\text { recommend the } \\
\text { franchise to a friend? }\end{array}$ & Sig. & .000 & .574 & .689 & .114 \\
\hline
\end{tabular}

The results of the MSQ scale are only tied with one psychological profile. One factor of the Big-Five, conscientiousness correlates with satisfaction at work.

To validate this result, partial correlations has been done for MSQ variables selecting two control items [In your present franchise, are you satisfied with the annual turnover you have achieved over the past three years? (0 to 10) and in your present franchise, are you satisfied with the profitability you have achieved over the past three years? (0 to 10)].

The results are significant except for the MSQ9 item. It confirms the fact that Conscientiousness is tied with satisfaction and it is consistent with literature.

Conscientiousness embodies characteristics such as responsibility, dependability and reliability, all of which are generally perceived as important characteristics for success in most jobs (Barrick and Mount, 1991; Murphy and Lee, 1994; Salgado, 1997). 
Cook (2006) writes in his dissertation 'Conscientiousness could be called the 'GMA' (General Mental Ability) of personality testing, in that it is a 'universal' predictor, predicting performance for all jobs in all contexts.'

Table 11 Links between MSQ scale and conscientiousness trait

\begin{tabular}{lll}
\hline & & \multicolumn{1}{c}{ Conscientiousness } \\
\hline Are you satisfied: & \\
MSQ1 & With your working conditions? & $0.2912(397) \mathrm{P}=0.000$ \\
MSQ2 & With the social status that your work gives you? & 0.2000 (397) $\mathrm{P}=0.000$ \\
MSQ3 & With the security of your job? & 0.1712 (397) $\mathrm{P}=0.000$ \\
MSQ4 & That you can use your personal qualities? & 0.3564 (397) $\mathrm{P}=0.000$ \\
MSQ5 & That you can take decisions on your own initiative? & 0.2079 (397) $\mathrm{P}=0.000$ \\
MSQ6 & With your occupation during the working day? & 0.1993 (397) $\mathrm{P}=0.000$ \\
MSQ7 & $\begin{array}{l}\text { That you can put into practice your own working } \\
\text { Methods? }\end{array}$ & 0.2367 (397) $\mathrm{P}=0.000$ \\
MSQ8 & With the feeling of achievement that your work & 0.2369 (397) $\mathrm{P}=0.000$ \\
MSQ9 & Witfers you? & -.239 (397) $\mathrm{P}=0.634$ \\
\hline
\end{tabular}

Despite the fact that Conscientiousness seems to be the most predictive factor, it is generally agreed that the others also contribute unique information since the Big-Five traits seem to be only minimally correlated. The other four personality dimensions have also been shown to be good predictors of job outcomes in certain contexts and for certain performance criteria (Barrick and Mount, 1991). In particular, Extroversion emerges as other strong predictors of many job criteria in a variety of job contexts (Murphy and Lee, 1994; Barrick and Mount, 1991). For example, Stewart and Carson (1995) found that, Extroversion was a valid predictor of overall performance for service workers. Salgado (1997) found Agreeableness to be a valid predictor for professionals, skilled labour and managers.

In order to deeper our research, potential links between different variables (sector and satisfaction; sector and psychological profile) have been analysed.

The table presents the results of one way ANOVA procedure for satisfaction and different sectors. Are there specific sectors where satisfaction at work is higher than elsewhere?

The results show that sectors present differences among the means concerning the MSQ (satisfaction at work). Household equipment has the higher mean, followed by non-specialised food trade.

In our sample, household equipment sector is represented by signs like Catena; Maison de la Literie; Cuisines Plus; non-specialised food trade sectors are associated with Casino, Huit à Huit and Champion. This king of franchise represents large volume distribution and is a speciality of French retail. Besides in this kind of shop, the number of employees is bigger than in the others. Professionalisation, formalisation, work specialisation, structures of these franchise networks and perhaps less competitive environment could explain the results. 
Table 12 ANOVA: MSQ scale and sectors

\begin{tabular}{|c|c|c|c|c|c|c|}
\hline & & $\begin{array}{c}\text { Sum of } \\
\text { squares }\end{array}$ & $d f$ & $\begin{array}{l}\text { Mean } \\
\text { square }\end{array}$ & $F$ & Sign \\
\hline \multirow[t]{3}{*}{ MSQ $*$ sector } & $\begin{array}{l}\text { Between } \\
\text { groups }\end{array}$ & $3,166.736$ & 6 & 527,789 & \multirow[t]{3}{*}{3.530} & \multirow[t]{3}{*}{.002} \\
\hline & $\begin{array}{l}\text { Within } \\
\text { groups }\end{array}$ & $58,913.828$ & 394 & 149,527 & & \\
\hline & Total & $62,080.564$ & 400 & & & \\
\hline \multirow{3}{*}{$\begin{array}{l}\text { In your present franchise, are } \\
\text { you satisfied with the annual } \\
\text { turnover you have achieved } \\
\text { over the past three years? } \\
\text { Sector }\end{array}$} & $\begin{array}{l}\text { Between } \\
\text { groups }\end{array}$ & 27.576 & 6 & 4,596 & \multirow[t]{3}{*}{.987} & \multirow[t]{3}{*}{.433} \\
\hline & $\begin{array}{l}\text { Within } \\
\text { groups }\end{array}$ & $1,833.860$ & 394 & 4,654 & & \\
\hline & Total & $1,861.436$ & 400 & & & \\
\hline \multirow{3}{*}{$\begin{array}{l}\text { In your present franchise, are } \\
\text { you satisfied with the } \\
\text { profitability you have achieved } \\
\text { over the past three years? * } \\
\text { Sector }\end{array}$} & $\begin{array}{l}\text { Between } \\
\text { groups }\end{array}$ & 28.550 & 6 & 4,758 & \multirow[t]{3}{*}{1.066} & \multirow[t]{3}{*}{.382} \\
\hline & $\begin{array}{l}\text { Within } \\
\text { groups }\end{array}$ & $1,758.074$ & 394 & 4,462 & & \\
\hline & Total & $1,786.623$ & 400 & & & \\
\hline
\end{tabular}

Table 13 Mean for MSQ by sectors

\begin{tabular}{lcc}
\hline Sector & MSQ mean & Std. dev \\
\hline Specialised food trade & 66.7647 & 14.94795 \\
Non-specialised food trade & 72.3542 & 10.74361 \\
Personal equipment & 66.8750 & 13.64328 \\
Household equipment & 74.6667 & 8.32034 \\
Other specialised non-food businesses & 70.1915 & 11.49790 \\
Services & 71.0141 & 13.10026 \\
Hotels and restaurants & 64.6667 & 10.40330 \\
\hline
\end{tabular}

The table presents the results of one way ANOVA procedure for psychological profile and different sectors. Are there specific sectors where specific Big-Five dimensions are more present than elsewhere?

The results show that sectors present difference among the means concerning introversion and neuroticism. Franchisees in the personal equipment sector are more extroverted and less neurotic. This is the same things for the 'Other non-food specialised business' sector.

The personal equipment sector is represented by shops of clothing Rodier, La Compagnie des Petits, Phildar and Petit Boy. Other non-food specialised business sector is also represented by small shops and require intensive for the franchisees work in the store. Franchisees spend a lot of time in social situations (customer services, empathy, advices, interactions...). Extravert personality is welcome for front office work.

Surprisingly, many franchisees are introverted and more neurotic. This does not mean that they are inevitably unsatisfied. Introversion could be compatible with back office positions (for example book keeping, procurement, stock management) or supra management when they are multi-unit-franchisees. 
Table 14 ANOVA big four and sectors

\begin{tabular}{lcccccc}
\hline & & $\begin{array}{c}\text { Sum of } \\
\text { squares }\end{array}$ & $d f$ & $\begin{array}{c}\text { Mean } \\
\text { square }\end{array}$ & F & Sign \\
\hline Conscientiousness & Between groups & 7.668 & 6 & 1.278 & 1.283 & .264 \\
$*$ sector & Within groups & 392.332 & 394 & .996 & & \\
& Total & 400.000 & 400 & & & \\
Introversion * & Between groups & 13.695 & 6 & 2.282 & 2.328 & .032 \\
sector & Within groups & 386.305 & 394 & .980 & & \\
& Total & 400.000 & 400 & & & \\
Neuroticism * & Between groups & 23.348 & 6 & 3.891 & 4.071 & .001 \\
sector & Within groups & 376.652 & 394 & .956 & & \\
& Total & 400.000 & 400 & & & \\
Intellect * sector & Between groups & 8.255 & 6 & 1.376 & 1.384 & .220 \\
& Within groups & 391.745 & 394 & .994 & & \\
\hline
\end{tabular}

Table 15 Mean of introversion and neuroticism by sectors

\begin{tabular}{lccc}
\hline Sector & & Introversion & Neuroticism \\
\hline Specialised food trade & Mean & .2918675 & -.2990319 \\
Non-specialised food trade & Std. dev & 1.1118841 & .7711232 \\
& Mean & .1840618 & .0412803 \\
Personal equipment & Std. dev & 1.0725109 & .9890077 \\
& Mean & -.2480941 & -.4619866 \\
Household equipment & Std. dev & .9328070 & .9537355 \\
& Mean & .0755007 & .1584567 \\
Other non-food specialised business & Std. dev & .8682368 & .8101825 \\
Services & Mean & -.1939205 & -.0164430 \\
& Std. dev & .9805601 & .9413035 \\
Hotels and restaurants & Mean & -.0142045 & .1760272 \\
& Std. dev & 1.0183331 & 1.0326850 \\
& Mean & .3403567 & .1656184 \\
\hline
\end{tabular}

\section{Directions for future research}

In summary, results of the current quantitative research among 400 franchisees indicate that conscientiousness is relevant to predict job satisfaction. The relations between satisfaction (MSQ) and the other factors of the Big-Five (introversion, neuroticism, intellectual) are not significant. Despite the fact that Conscientiousness seems to be the most predictive factor for satisfaction, results show that the other Big-Five traits are 
specific in several sectors. The type of franchisees activity is a contextual variable. For example, extraversion characterises the personality of franchisees working in the personal equipment sector. This specific trait does not explain franchisee's satisfaction but is certainly essential to reach customer's satisfaction.

Literature shows that Big-Five personality dimensions, not just Conscientiousness, have value as predictors of job performance. If this study proves that franchisees' satisfaction is tied with Conscientiousness, future research concerning the Big-Five and franchisee's different job criteria or job performance (commitment to the organisation, workplace stress, job strain, market oriented organisation, customer orientation, leadership, supervision, motivation in the workplace, interpersonal communication etc...) should be developed in future research.

\section{Acknowledgements}

This research was funded by the French Franchise Federation. The project was initiated and coordinated by Professor Michel Kalika.

\section{References}

Barrick, M. and Mount, M. (1991) 'The Big Five personality dimensions and job performance: a meta analysis', Personnel Psychology, Vol. 44, No. 2, pp.1-26.

Borkenau, P. and Ostendorf, F. (1998) 'The Big Five as states: how useful is the five-factor model to describe intraindividual variations over time?', Journal of Personality, Vol. 32, No. 2, pp.202-221.

Brayfield, A.H. and Rothe, H.F. (1951) 'An index of job satisfaction', Journal of Applied Psychology, Vol. 35, No. 5, pp.307-311.

Catell, R. (1965) The Scientific Analysis of Personality, Penguin Book, Baltimore.

Connolly, J.J. and Viswesvaran, C. (2000) 'The role of affectivity in job satisfaction: a meta-analysis', Personality and Individual Differences, Vol. 29, No. 2, pp.265-281.

Cook, V. (2006) An Investigation of the Construct Validity of the Big Five Construct of Emotional Stability in Relation to Job Performance, Job Satisfaction, and Career Satisfaction, ProQuest/UMI Publisher.

Costa, P. and McCrae, R. (1988) 'From catalog to classification: Murray's need and the five-factor model', Journal of Personality \& Social Psychology, Vol. 55, No. 2, pp.258-265.

Costa, P.T. and McCrae, R.R. (1992) 'Four ways five factors are not basic: reply', Personality and Individual Differences, Vol. 13, No. 8, pp.861-865.

DeNeve, K.M. and Cooper, H. (1998) 'The happy personality: a metaanalysis of 137 personality traits and subjective well-being', Psychological Bulletin, Vol. 124, No. 2, pp.197-229.

Emmons, R.A., Diener, E. and Larsen, R.J. (1985) 'Choice of situations and congruence models of interactionism', Personality and Individual Differences, Vol. 6, No. 6, pp.693-702.

Heneman, R., Greenberger, D. and Anonyuo, C. (1989) 'Attributions and exchanges: the effects of interpersonal factors on the diagnosis of employee performance', Academy of Management Journal, Vol. 32, No. 2, pp.466-476.

Hing, N. (1995) 'Franchisee satisfaction: contributors and consequences', Journal of Small Business Management, Vol. 33, No. 2, pp.12-25. 
Hing, N. (1997) 'Developing a model of franchisee buying behaviour based on the Australian restaurant industry: directions for future research', Franchising Research: An International Journal, Vol. 2, No. 4, pp.152-166.

John, O., Angleitner, A. and Ostendorf, F. (1988) 'The lexical approach to personality: a historical review of trait taxonomic research', European Journal of Personality, Vol. 2, No. 3, pp.171-203.

Judge, T., Heller, D. and Mount, K. (2002) 'Five-factor model of personality and job satisfaction: a meta-analysis', Journal of Applied Psychology, Vol. 87, No. 3, pp.530-541.

Lewis, M.C. and Lambert, D.M. (1991) 'A model of channel member performance, dependence and satisfaction', Journal of Retailing, Vol. 67, No. 2, pp.205-225.

Magnus, K., Diener, E., Fujita, F. and Pavot, W. (1993) 'Extraversion and neuroticism as predictors of objective life events: a longitudinal analysis', Journal of Personality and Social Psychology, Vol. 65, No. 5, pp.1046-1053.

McCrae, R.R. and Costa, P.T. (1991) 'The NEO personality inventory: using the five factor model in counseling', Journal of Counseling and Development, Vol. 69, No. 4, pp.367-372.

Morrison, K. (1997) 'How franchise job satisfaction and personality affects performance, organizational commitment, franchisor relations, and intention to remain', Journal of Small Business Management, Vol. 35, No. 3, pp.39-67.

Mount, M.K, Barrick, M.R. and Stewart, G.L. (1998) 'Five-factor model of personality and performance in jobs involving interpersonal interactions', Human Performance, Vol. 11, Nos. 2-3, pp.145-165.

Murphy, K.R. and Lee, S.L. (1994) 'Personality variables related to integrity test scores: the role of conscientiousness', Journal of Business and Psychology, Vol. 8, No. 4, pp.413-424.

Organ, D.W. and Lingl, A. (1995) 'Personality, satisfaction, and organizational citizenship behavior', Journal of Social Psychology, Vol. 135, No. 3, pp.339-350.

Peabody, D. (1987) 'Selecting representative trait adjectives', Journal of Personality and Social Psychology, Vol. 52, No. 1, pp.352-367.

Peabody, D. and Goldberg, L. (1989) 'Some determinants of factor structures from personality-trait descriptors', Journal of Personality and Social Psychology, Vol. 57, pp.352-367.

Pervin, L. and John, O. (2001) 'Trait theory: the five-factor model; applications and evaluations of trait approaches to personality', Personality: Theory and Research, ed., pp.253-296, John Wiley \& Co.

Robertson, I., Gibbons, P., Baron, H., MacIver, R. and Nyfield, G. (1999) 'Understanding management performance', British Journal of Management, Vol. 10, No. 1, pp.5-12.

Salgado, J.F. (1997) 'The five factor model of personality and job performance in the European community', Journal of Applied Psychology, Vol. 82, No. 1, pp.30-43.

Schell, B. and McGillis, S (1990) 'Personality and attitudinal predictors of commitment for franchisees', Journal of Small Business \& Entrepreneurship, Vol. 7, No. 3, pp.40-62.

Schul, P.L., Little, T.E. and Pride, W.M. (1985) 'Members' satisfaction', Journal of Retailing, Vol. 61, No. 2, pp.9-38.

Stewart, G.L. and Carson, K.P. (1995) 'Personality dimensions and domains of service performance: a field investigation', Journal of Business and Psychology, Vol. 9, No. 4, pp.365-378.

Tett, R.P., Jackson, D.N. and Rothstein, M. (1991) 'Personality measures as predictors of job performance: a meta-analytic review', Personnel Psychology, Vol. 44, No.4, pp.703-742.

Tuunanen, M. (1999) 'Franchisees' satisfaction: preliminary findings from national study', Academy of Marketing Studies Journal, Vol. 3, No. 2, pp.41-56. 
Watson, D. and Clark, I. (1992) 'On traits and temperament: general and specific factors of emotional experience and their relation to the five-factor model', Journal of Personality, Vol. 60, pp.441-475.

Weiss, D., Dawis, R., England, G. and Lofquist, L. (1967) 'Manual for the Minnesota satisfaction questionnaire', Minnesota Studies in Vocational Rehabilitation, Vol. 22, Minnesota University.

White, J., Hendrick, S. and Hendrick, C. (2004) 'Big five personality variables and relationship constructs', Personality and Individual Differences, Vol. 37, No. 7, pp.1519-1530.

\section{Notes}

1 Europe's leading market research institute (http://www.gfk.fr/). 